\title{
Molecular characterization and amplified ribosomal DNA restriction analysis of entomopathogenic bacteria associated with Rhabditis (Oscheius) spp.
}

\author{
Balakrishnan Geetha Sangeetha ${ }^{1}$ Cheruvandasseri Arumughan Jayaprakas ${ }^{1}$ • \\ Jinachandrannair Vijayakumari Siji ${ }^{1}$ Moochattil Rajitha ${ }^{1}$. \\ Basheerkutty Shyni ${ }^{1} \cdot$ Chellappan Mohandas ${ }^{1}$
}

Received: 24 November 2014/ Accepted: 19 June 2015/Published online: 14 January 2016

(C) The Author(s) 2016. This article is published with open access at Springerlink.com

\begin{abstract}
Bacterial strains associated with entomopathogenic nematodes (EPNs) Rhabditis (Oscheius) spp. were isolated from infected cadavers of Galleria mellonella. The obtained 18 isolates were subdivided into nine phylogenetically different genera based on comparative sequence analysis of their 16S rRNA genes. The isolates were affiliated to three different class namely $\gamma$ proteobacteria (Enterobacter, Proteus, Providencia, Pseudomonas, Stenotrophomonas), $\beta$-proteobacteria (Alcaligenes) and Bacilli (Bacillus, Enterococcus, Lysinibacillus). It was observed that Gram-positive strains (Bacilli) were more frequently associated with the EPN, whereas Gram-negative isolates were affiliated to six different genera with more genotypic diversity. Subsequently, all bacterial isolates used in this study were analyzed by amplified ribosomal DNA restriction analysis (ARDRA). Eight restriction endonucleases (CfoI, HinfI, RsaI, DdeI, Sau3AI, AluI, HaeIII, and MspI) were examined and a total of 15 different genotypes were obtained, forming two heterogenous main clusters after analysis by un-weighted pair-group method using arithmetic averages.
\end{abstract}

Keywords Bacillus - Enterobacter - Entomopathogenic nematode $\cdot 16 \mathrm{~S}$ rDNA

Cheruvandasseri Arumughan Jayaprakas prakashcaj@gmail.com

1 Division of Crop Protection, Central Tuber Crops Research Institute, Sreekariyam, Trivandrum, Kerala, India

\section{Introduction}

Entomopathogenic nematodes (EPNs) lead a symbiotic association with specific enterobacteria. Xenorhabdus and Photorhabdus are two genera of bacteria that are symbiotically associated with specific nematodes belonging to the families Steinernematidae and Heterorhabditidae, respectively (Poinar 1990). The nematodes invade the larvae of susceptible insects and penetrate to the hemocoel, where they release their symbiotic bacteria. The bacteria proliferates, kills the insect larvae, and promotes nematode reproduction by providing nutrients from the actions of degradative enzymes on the insect cadaver and by producing antibiotics that inhibit the growth of other microorganisms (Akhurst and Boemare 1990). A striking feature of Xenorhabdus and Photorhabdus is phase variation, which affects a large number of membrane-bound, intra and extracellular proteins and secondary metabolites (Akhurst 1996; Forst et al. 1997). Phase I variants are involved in the symbiotic relationship with EPN and are isolated from the non-feeding infective stage nematodes and from the body cavities of insects killed by these nematodes. No role in symbiosis has yet been determined for phase II, which is associated only with EPN under laboratory conditions. They represent one important part of the spectrum of biocontrol agents that are used to control insect pests of economically important crops. The importance of entomopathogenic bacteria (EPB) as source for the discovery of antibacterial and antifungal molecules has been studied in depth, as highlighted in various reviews (Paul et al. 1981; Webster et al. 2002; Bode 2009).

Rhabditis (Oscheius) spp. isolated from different agroclimatic zones of Kerala resembles EPN and was found to be effective for the control of areca nut spindle bug in the field (Mohandas et al. 2004). These were found to kill a 
number of important insect pests within $24-72 \mathrm{~h}$ in laboratory conditions. Rhabditis (Oscheius) sp. was also reported as biological control agent against rice yellow stem borer, Scirpophaga incertulas (Walker) (Padmakumari et al. 2007). Deepa et al. (2011) isolated twelve different strains of symbiotic bacteria from the surface sterilized infective juveniles (IJs) of R. (Oscheius) spp. and sequencing of $16 \mathrm{~S}$ rDNA of these isolates revealed that they belong to seven different genera viz. Acinetobacter, Bacillus, Comamonas, Stenotrophomonas, Achromobacter, Klebsiella and Brucellaceae. Three diketopiperazines viz cyclo(L-Pro-L-Leu), cyclo(D-Pro-L-Leu) and cyclo-(D-ProL-Tyr) with antimicrobial activity were isolated from Bacillus cereus associated with a Rhabditis (Oscheius) sp. (Kumar et al. 2012a). Two stilbenes viz 3,4',5-trihydroxystilbene and 3,5-dihydroxy-4-isopropylstilbene with antimicrobial activity were also isolated from the same bacterium associated with Rhabditis (Oscheius) sp. (Kumar et al. 2012b). Tryptophan containing diketopiperazines viz cyclo-(L-Trp-L-Pro), cyclo-(L-Trp-L-Tyr), cyclo-(L-Trp-LIle), cyclo-(L-Trp-L-Leu) and cyclo-(L-Trp-L-Phe) with antibacterial activity against human pathogenic bacteria were isolated from Comamonas testosteroni associated with $R$. (Oscheius) sp. (Kumar et al. 2014a).

A number of studies have been carried out on the phylogenetic status of bacteria associated with EPN using $16 \mathrm{~S}$ rRNA gene sequencing. Xenorhabdus and Photorhabdus spp. appear to display a high monophyletic diversity. The 16S rRNA gene sequence analysis has placed the Xenorhabdus/Photorhabdus group within the gamma subdivision of the purple bacteria (Proteobacteria) (Rainey et al. 1995). In both genera, identification of new bacterial species is difficult because most strains are phenotypically very similar and fail to give positive results in many biochemical tests for identification (Boemare and Akhurst 1988). Amplified ribosomal DNA restriction analysis (ARDRA) proved to be useful for the classification of bacterial strains at different taxonomic levels and to analyze the genetic variability between bacterial isolates depending on selection of conserved or variable regions in the ribosomal genes (Swings 1996; Tiedje 1996). Brunel et al. (1997) conducted a study about the fast and rapid identification of Xenorhabdus and Photorhabdus spp. by restriction analysis of PCR amplification of 16S rRNA gene and phylogenetic dendrogram was also constructed by the neighbor joining method. Fischer-Le Saux et al. (1998) also reported the PCR ribotyping of Xenorhabdus and Photorhabdus isolated from the Caribbean region in relation to the geographic distribution of their nematode host based on 16S rRNA and cluster analysis. Clarridge (2004) has studied the impact of 16S rRNA gene sequencing for the phylogeny and taxonomy of bacteria. All isolated bacteria viz Enterobacter aerogenes, E. hormaechei, E. cancerogenus, Stenotrophomonas maltophilia, Pseudomonas fulva/parafulva were Gram-negative except Staphylococcus succinus (Lambert) (Gouge and Snyder 2006). In addition to $X$. cabanillasii, other bacterial strains were isolated from Steinernema riobrave and identified to species level by 16S rDNA sequences (Christen et al. 2008).

The EPB associated with $R$. (Oscheius) sp. represent an important source of bioactive molecules with antibacterial and anticancer activity (Kumar et al. 2014b). Moreover, earlier reports also suggest that the EPN associated bacterial isolates were found to kill a number of agriculturally important insect pests (Deepa et al. 2010). Here, we present the identification and diversity of bacterial isolates based on phenotypic characteristics, molecular phylogenetic analysis of 16S rRNA gene sequence and amplified ribosomal DNA restriction analysis (ARDRA).

\section{Materials and methods}

\section{Isolation of bacteria from insect hemolymph}

The most common insect host used for in vivo production of EPN is the last instar of the greater wax moth ( $G$. mellonella), because of its high susceptibility to most nematodes, ease in rearing, wide availability and ability to produce high yields (Flanders et al. 1996; Ehlers 2001). Late instars of G. mellonella were placed on the surface of a filter paper in $35 \mathrm{~mm}$ Petri dishes. Individual nematodes were transferred onto the filter paper surface at a dose rate of 400 per Petri dish. All the dishes were sealed with parafilm, and then incubated at $25{ }^{\circ} \mathrm{C}$ for $24 \mathrm{~h}$. Thereafter, the dead larvae were removed, rinsed in distilled water and surface sterilized with $70 \%$ ethanol, and left for drying in a laminar air flow cabinet. Hemolymph obtained by dissecting dorsally between the fifth and sixth interstitial segments was collected with a sterile loop and streaked on nutrient agar (NA) plates (Woodring and Kaya 1988) and incubated at $28{ }^{\circ} \mathrm{C}$ for $48 \mathrm{~h}$. The sources of the nematodes used in this study are listed in (Table 1).

\section{Phenotypic characterization}

Phenotypic characteristics of each colony were studied from the standard array of morphological characters such as form, margin, color, elevation of colony by using stereomicroscope (Carl Zeiss, Stemi 2000C, USA) under $40 \times$ magnification. Gram staining and spore staining specific for identification of unknown bacterial strains were performed using 24-h bacterial culture on nutrient broth. Various biochemical tests such as citrate, nitrate reduction test, ortho-nitrophenyl- $\beta$-galactoside (ONPG), indole, methyl red, Voges-Proskauer, urease, motility indole 
Table 1 Geographic locations from where EPNs were collected

\begin{tabular}{lll}
\hline Bacterial isolate & Nematode & Location \\
\hline SCI & Rhabditis (Oscheius) sp. & Mudavanmugal, Kerala \\
KL & Rhabditis (Oscheius) sp. & Korani, Kerala \\
KPG & Rhabditis (Oscheius) sp. & Kannur, Kerala \\
KY1 & Rhabditis (Oscheius) sp. & Kaniyoor, Kerala \\
HY & Rhabditis (Oscheius) sp. & Bangalore, Karnataka \\
KAL & Rhabditis (Oscheius) sp. & Kallambalam, Kerala \\
352 & Rhabditis (Oscheius) sp. & Trivandrum, Kerala \\
MA1 & Rhabditis (Oscheius) sp. & Manampur, Kerala \\
D & Rhabditis (Oscheius) sp. & Thiruvananthapuram, Kerala \\
SBI & Rhabditis (Oscheius) sp. & Coimbatore, Tamilnadu \\
TN5 & Rhabditis (Oscheius) sp. & Tirunelveli, Tamilnadu \\
TAH & Rhabditis (Oscheius) sp. & Alwarkurichi, Tamilnadu \\
MM3 & Rhabditis (Oscheius) sp. & Maruthamalai, Tamilnadu \\
MM2 & Rhabditis (Oscheius) sp. & Maruthamalai, Tamilnadu \\
F34 & Rhabditis (Oscheius) sp. & Coimbatore, Tamilnadu \\
KK2 & Rhabditis (Oscheius) sp. & Kanyakumari, Tamilnadu \\
BR1 & Rhabditis (Oscheius) sp. & Bangalore, Karnataka \\
S & Rhabditis (Oscheius) sp. & Soharpur, Orissa \\
\hline
\end{tabular}

ornithine (MIO), oxidase and catalase test were conducted according to the standard procedure of Cappuccino and Sherman (1996) and were interpreted 24-48 h later. For carbohydrate fermentation tests, $1 \%$ of each test sugar (glucose, glycerol, maltose, mannitol, sucrose, starch, fructose, cetrimide and lactose) in peptone water was used. All the chemicals for biochemical test were purchased from the Himedia Laboratories Limited, Mumbai, India. Biochemical properties of the isolates have been studied and compared with Garrity et al. 2005

\section{Amplification of 16S rDNA}

Total genomic DNA of bacteria was extracted according to the protocol (Reinhardt et al. 2008). Bacterial 16S rDNA was amplified using bacterial universal primers: forward primer fD1 5'AGAGTTTGATCCTGGCTCAG3' (corresponding to 8-27 of E. coli) and reverse primer RP2 $5^{\prime}$ CGGCTACCTTGTTACGACTT3' (corresponding to $^{\prime}$ 1492-1510 of E. coli) (Weisburg et al. 1991). PCR was performed in a final volume of $25 \mu$ reaction containing $2.5 \mu \mathrm{l}$ of $10 \times$ Taq buffer A (containing $15 \mathrm{mM} \mathrm{MgCl}_{2}$ ), $0.5 \mu l 10 \mathrm{mM}$ dNTPs (2.5 mM each), $1.0 \mu \mathrm{l}$ of each primer $(20 \mathrm{ng}), 2 \mu \mathrm{l}$ of template DNA and $0.25 \mu \mathrm{l}$ of (1U) Taq DNA polymerase (Bangalore GeNei, India). The amplification conditions were $92{ }^{\circ} \mathrm{C}$ for 2 min $10 \mathrm{~s}$ followed by 30 cycles of $1 \mathrm{~min} 10 \mathrm{~s}$ at $94{ }^{\circ} \mathrm{C}, 30 \mathrm{~s}$ at $49{ }^{\circ} \mathrm{C}$ and $2 \mathrm{~min}$ at $72{ }^{\circ} \mathrm{C}$ and followed by $10 \mathrm{~min}$ at $72{ }^{\circ} \mathrm{C}$. The amplified products were resolved on $1 \%$ agarose gel containing ethidium bromide $0.5 \mu \mathrm{g} / \mathrm{ml}$. The DNA bands were visualized under UV transilluminator and documented with Gel Doc system (Alpha imager, Alpha Innotech, USA). DNA ladder of 500 bp (Bangalore GeNei, India) was used for determining the size of the amplicon.

The 16S rDNA gene sequences were generated by sequencing the PCR product on Applied Biosystems 3500 Genetic Analyzer (Big Dye Terminator v 3.1). The sequences obtained for the bacterial isolates were aligned with secondary-structure based Infernal aligner (https://rdp. cme.msu.edu/). The nucleotide sequences were compared with those in the NCBI databases using the Basic Local Alignment Search Tool (BLAST, http://www.ncbi.nlm.nih. gov/BLAST). From the aligned sequences phylogenetic tree was constructed using MEGA 6.06 software (Tamura et al. 2013).

The 16S rRNA gene sequences have been deposited in the NCBI Gen Bank with the following accession numbers: BR1 (JN712651), D (KJ578727), F34 (KJ600626), HY (KJ935725)，KPG (JN982043)，KK2 (JX470956)， SBI (JX470955)，KAL (JX470957)，KY1 (JX470960)，KL (KJ578730), MA1 (KJ600625), MM2 (KJ600624), MM3 (JN712652), S (JX470961), SCI (KJ600627), TN5 (KJ578729), TAH (KJ578730), 352 (KJ935726).

\section{Amplified ribosomal DNA restriction analysis (ARDRA)}

For each isolate, $10 \mu \mathrm{l}$ of PCR-amplified 16S rDNA was digested for $4 \mathrm{~h}$ at $37{ }^{\circ} \mathrm{C}$ with $5 \mathrm{U}$ of restriction endonuclease CfoI, HinfI, RsaI, DdeI, Sau3AI, AluI, HaeIII, and MspI (Bangalore GeNei, India) according to the 
manufacturer's instructions and separated by electrophoresis on $2 \%$ agarose gels in $1 \times$ Tris-acetate-EDTA buffer for $2 \mathrm{~h}$ at $70 \mathrm{~V}$. The gels were stained and photographed as described above. For each restriction enzyme's band, a binary data matrix was constructed on the basis of the presence or absence of each band. The band patterns obtained with each enzyme were combined to obtain a single pattern for each isolate. Dendrogram was constructed by un-weighted pair-group method using arithmetic averages (UPGMA) with MEGA 6.06 software (Tamura et al. 2013).

\section{Results}

\section{Phenotypic characterization}

Morphological characters of colonies observed on NA plates were different for each bacterial strains and with entirely different biochemical characteristics from those exhibited by genera Xenorhabdus and Photorhabdus (Table 2). Pigmentation was not observed for the bacterial colonies. Colonies formed on NA plates were irregular, raised, convex or flat, white in color, with lobate, serrate or undulate margins. Correlation between strain characteristics and geographic locations where nematodes samples were collected was not observed in this study. Endospores were observed for the isolates BR1, HY, KPG, KY1, KAL, KK2, SBI and SCI on NA plates within $48 \mathrm{~h}$ of incubation at $30{ }^{\circ} \mathrm{C}$. The spores were central or subterminal in position with one or two within a cell. All the strains gave a negative reaction for indole, ONPG, Voges-Proskauer test and positive reaction for methyl red and catalase test. It was also observed that biochemical characters exhibited by the isolates were different for each bacterial strains and most of the isolates gave variable responses for carbohydrate fermentation tests.

The isolate MM2 and KL show similar phenotypic characteristics of Alcaligenes faecalis except for fructose, maltose fermentation test. A. faecalis does not produce acid but the isolates utilize fructose and maltose as sole source of carbon. Key positive characteristics for Enterococcus faecalis are non-motile, catalase negative and ferment glucose without gas production. The strains TAH and TN5 were motile and catalase positive, which indicates different strain characteristics. Biochemical characters of isolate 352 were similar to Lysinibacillus sphaericus but the strain showed positive reaction for fructose, maltose, starch and glucose fermentation test. Stenotrophomonas maltophilia were oxidase negative but MM3 isolate shows positive reaction for oxidase. Strain $\mathrm{S}$ shows negative reaction for citrate and positive for methyl red. But Pseudomonas strains always gave positive reaction for citrate and negative for methyl red. Isolates D, F34 and MA1 show similar phenotypic characteristics of Proteus mirabilis, Providencia sp. and Enterobacter sp., respectively. The colony morphological characters and the biochemical test results of all the isolates are shown in (Table 3).

\section{S rDNA sequence analysis}

Sequences with $>98 \%$ sequence similarity to their nearest phylogenetic neighbor were identified to the species level. The 18 different strains were affiliated to nine different genera by comparative analysis of $16 \mathrm{~S}$ rDNA sequences. The isolates were identified as MM2 and KL-A. faecalis, TN5 and TAH-E. faecalis, D-P. mirabilis, 352-L. sphaericus, MM3-S. maltophilia, MA1-Enterobacter sp., F34Providencia sp. and S- Pseudomonas sp. Sequence similarity analysis of the strains BR1, HY, KPG, KY1, KAL, $\mathrm{KK} 2$, SBI, and SCI shows that they were closely related to B. cereus with more than $98 \%$ similarity. BLAST results were shown in Table 4. Phylogenetic relationship of Gramnegative and Gram-positive bacteria based on 16S rRNA gene sequences is shown in Figs. 1, 2.

\section{Amplified ribosomal DNA restriction analysis (ARDRA)}

All the 18 isolates were further investigated by amplified ribosomal DNA restriction analysis (ARDRA). Polymorphic restriction patterns of PCR-amplified $16 \mathrm{~S}$ rDNA were obtained with the AluI and HaeIII endonucleases. Results of the restriction analysis patterns are presented in Figs. 3, 4 , respectively. A total of 15 genotypes were identified, forming two heterogenous main clusters based on dendrogram (Fig. 5) after analysis by un-weighted pair-group method using arithmetic averages (UPGMA).

\section{Discussion}

The present study describes the molecular characterization of EPB isolated from $R$. (Oscheius) sp. and based on the $16 \mathrm{~S}$ rDNA sequence analysis, the 18 isolates were identified as Enterobacter sp., P. mirabilis, Providencia sp., Pseudomonas sp., S. maltophilia (class $\gamma$-proteobacteria), A. faecalis (class $\beta$-proteobacteria) and B. cereus, E. faecalis, L. sphaeriscus (class Bacilli). The restriction analysis data of PCR-amplified $16 \mathrm{~S}$ rDNA of the isolates revealed that they came under 15 different genotypes and were grouped into two heterogenous main clusters based on dendrogram.

In the current investigation, the EPB were isolated from EPNs Rhabditis (Oscheius) sp. which belongs to the family 


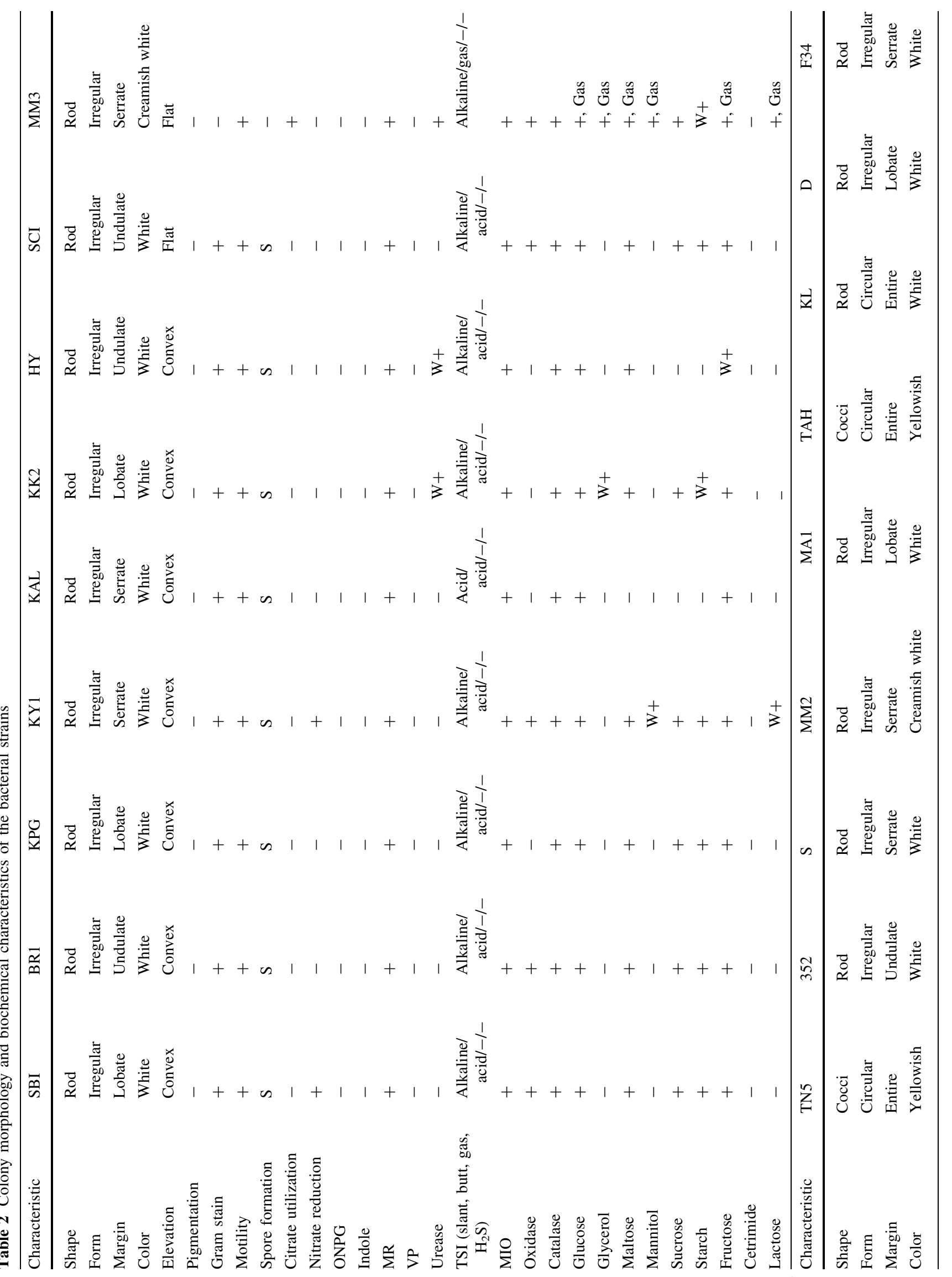


32 Page 6 of 13

3 Biotech (2016) 6:32

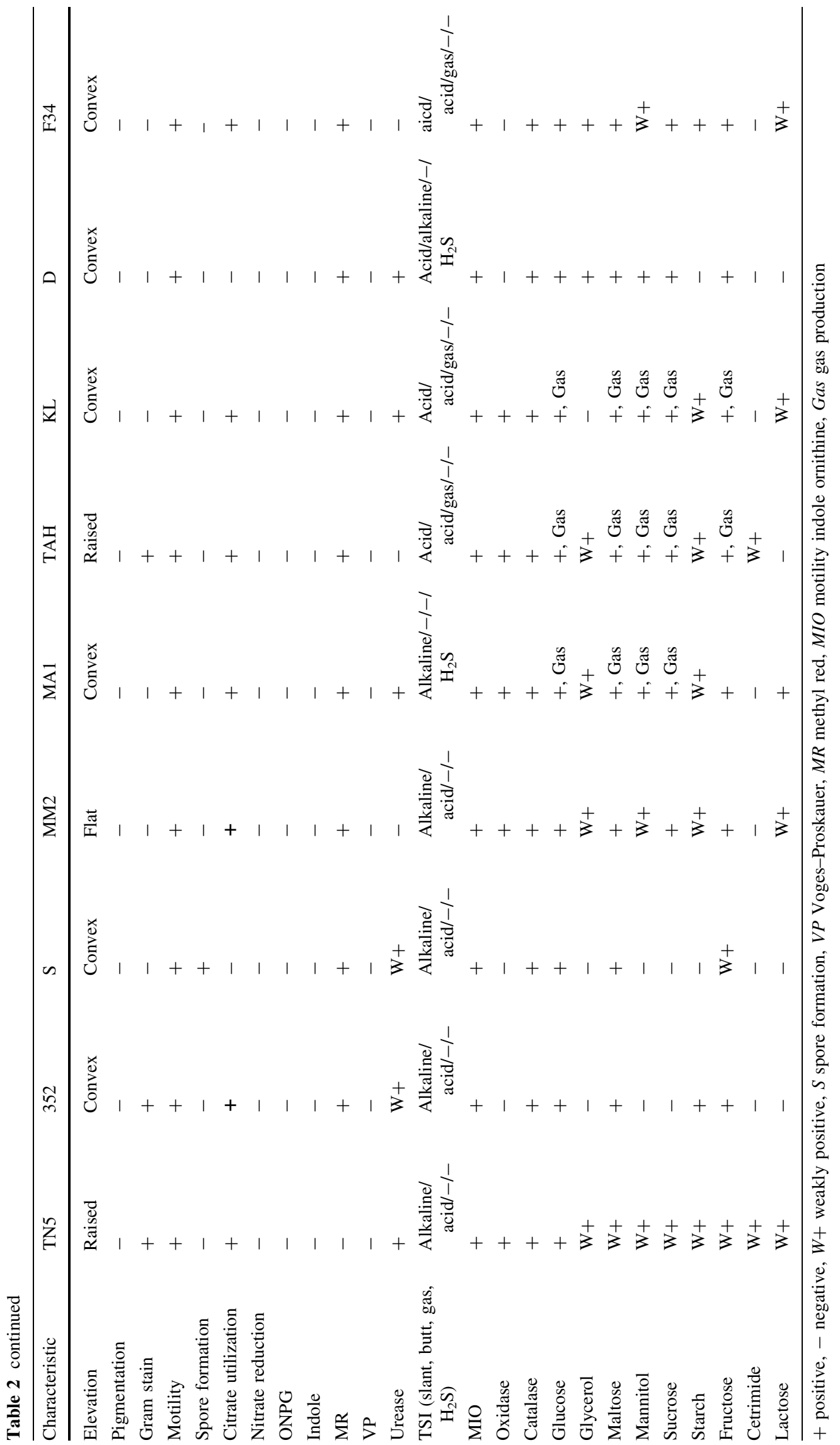

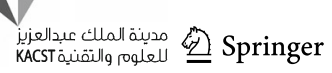


Table 3 Identification of bacterial species associated EPN based on sequencing of 16S rDNA

\begin{tabular}{llcl}
\hline Isolate & Identification & $E$ value & Similarity (\%) \\
\hline SCI & Bacillus thuringiensis strain Bt407 16S ribosomal RNA, complete sequence (NR 102506) & 0.0 & 98 \\
SBI & Bacillus cereus strain ATCC 14579 16S ribosomal RNA gene, partial sequence (NR 114582) & 0.0 & 99 \\
KK2 & Bacillus cereus strain ATCC 14579 16S ribosomal RNA (rrnA) gene, complete sequence (NR 074540) & 0.0 & 99 \\
HY & Bacillus cereus strain CCM 2010 16S ribosomal RNA gene, complete sequence (NR 115714) & 0.0 & 99 \\
KAL & Bacillus cereus strain NBRC 15305 16S ribosomal RNA gene, partial sequence (NR 112630) & 0.0 & 98 \\
KPG & Bacillus cereus strain JCM 2152 16S ribosomal RNA gene, partial sequence (NR 113266) & 0.0 & 98 \\
BR1 & Bacillus cereus strain ATCC 14579 16S ribosomal RNA (rrnA) gene, complete sequence (NR 074540) & 0.0 & 98 \\
KY1 & Bacillus cereus strain IAM 12605 16S ribosomal RNA gene, partial sequence (NR 115526) & 0.0 & 99 \\
352 & Lysinibacillus sphaericus C3-41 16S ribosomal RNA, complete sequence (NR 074883) & 0.0 & 99 \\
F34 & Providencia stuartii strain MRSN 2154 16S ribosomal RNA, complete sequence (NR 102978) & 0.0 & 98 \\
D & Proteus mirabilis strain HI4320 16S ribosomal RNA, complete sequence (NR 074898) & 0.0 & 97 \\
MM2 & Alcaligenes faecalis strain NBRC 13111 16S ribosomal RNA gene, partial sequence (NR 113606) & 0.0 & 97 \\
KL & Alcaligenes faecalis strain NBRC 13111 16S ribosomal RNA gene, partial sequence (NR 113606) & 0.0 & 98 \\
TN5 & Enterococcus faecalis V583 strain V583 16S ribosomal RNA, complete sequence (NR 074637) & 0.0 & 97 \\
MM3 & Stenotrophomonas maltophilia strain IAM 12423 16S ribosomal RNA gene, complete sequence (NR 041577) & 0.0 & 99 \\
S & Pseudomonas monteilii 16S ribosomal RNA, complete sequence (NR 121767) & 0.0 & 99 \\
MA1 & Enterobacter hormaechei strain 0992 77 16S ribosomal RNA gene, partial sequence (NR 042154) & 0.0 & 98 \\
TAH & Enterococcus faecalis strain ATCC 19433 16S ribosomal RNA gene, partial sequence (NR 115765) & 0.0 & 98 \\
\hline & &
\end{tabular}

Rhabditidae. Zhang et al. (2008) and Chaston et al. (2011) opined that EPB are usually associated with EPNs of the family Steinernematidae, Heterorhabditidae and Rhabditidae. Gram-negative enterobacteria of the genera Xenorhabdus and Photorhabdus are the most studied mutualistic symbionts of the EPNs Steinernema and Heterorhabditis (Boemare et al. 1993; Forst and Clarke 2002; Chaston et al. 2011). The molecular and cellular interface between the host and the bacteria during the colonization process is the reason for unique nematodebacterium association (Goodrich-Blair and Clarke 2007; Snyder et al.2007). The complete genome sequence data of Xenorhabdus and Photorhabdus sp. revealed a set of common genes encoding toxins, proteases, putative membrane transporters, transcriptional regulators and genes encoding lipopolysaccharide production, which help in stabilizing the nematode-bacterium mutualism (Chaston et al. 2011).

The EPB isolated in this study has been reported to have biocontrol activity (Deepa et al. 2010; Mohandas et al. 2007). Many nematode species such as (Rhabditis (Oscheius) sp., Rhabditis blumi, Heterorhabditidoides chongmingensis, Heterorhabditidoides rugaoensis of the family Rhabditidae have association with EPB and together act as potent biological control agent (Zhang et al. 2008, 2012; Park et al. 2012). The insect pathogenic bacteria viz Providencia vermicola, A. faecalis and Flavobacterium sp. isolated from $R$. blumi have pathogenic effect on major cruciferous vegetable pests such as Plutella xylostella L., Artogeia rapae L., Mamestra brassicae L. (Park et al.
2011, 2012). Out of the 18 strains isolated from the Rhabditis (Oscheius) sp. 11 strains were identified as $B$. cereus. Associations between endospore forming Paenibacillus nematophilus, and $H$. megidis have already been reported (Enright et al. 2003). A Bacillus sp. was also reported to have phoretic relationship with the EPN, Heterorhabditis sp. (Marti and Timper 1999). The insecticidal activity of $B$. cereus by producing insecticidal proteins named Vip during the vegetative phase which in turn causes pathogenicity to insects of order Lepidoptera and Diptera reported by To et al. (1975), Kaaya and Darji (1989), Warren et al. (1996). Kumar et al. (2014a) reported antimicrobial property of the metabolites isolated from $B$. cereus associated with Rhabditis (Oscheius) sp. L. sphaericus is the first report to have its association with IJs of EPN. Although L. sphaeriscus was reported as an entomopathogen and produces toxin like sphaericolysin leading to haemocoelic toxicity toward Blattela germanica and Spodoptera litura (Castagnola and Stock 2014). It was the first report of the bacterium to have its association with IJs of EPN. The 16S rRNA gene sequencing of the isolates TN5 and TAH shared $98 \%$ similarity with E. faecalis (NR 074637 and NR 115765). Walsh and Webster (2003) also reported the occurrence of two bacterial species viz. Acinetobacter and Enterococcus from Steinernema in addition to Xenorhabdus symbionts.

The Gram-negative isolates associated with Rhabditis (Oscheius) sp. belong to six different genera of class $\gamma$ proteobacteria and $\beta$-proteobacteria. Similar studies also reported isolation of Gram-negative EPB of different 
Table 4 Comparison of morphological and biochemical characteristics of the bacterial strains with Xenorhabdus and Photorhabdus sp

\begin{tabular}{|c|c|c|c|c|c|c|c|c|c|c|c|c|c|}
\hline Characteristic & \multicolumn{2}{|l|}{ SBI } & BR1 & \multicolumn{2}{|l|}{ KPG } & KY1 & KAL & \multicolumn{2}{|c|}{ KK2 } & HY & \multicolumn{2}{|l|}{ SCI } & MM3 \\
\hline Shape & \multicolumn{2}{|l|}{ Rod } & Rod & Rod & & Rod & Rod & \multicolumn{2}{|c|}{ Rod } & Rod & \multicolumn{2}{|l|}{ Rod } & Rod \\
\hline Form & \multicolumn{2}{|c|}{ Irregular } & Irregular & \multicolumn{2}{|c|}{ Irregular } & Irregular & Irregular & \multicolumn{2}{|c|}{ Irregular } & Irregular & \multicolumn{2}{|c|}{ Irregular } & Irregular \\
\hline Pigmentation & \multicolumn{2}{|l|}{-} & - & - & - & & - & - & & - & - & & - \\
\hline Gram stain & + & & + & + & + & & + & + & & + & + & & - \\
\hline Bioluminescence & - & & - & - & - & & - & - & & - & - & & - \\
\hline Motility & + & & + & + & + & & + & + & & + & + & & + \\
\hline Spore formation & $\mathrm{S}$ & & $\mathrm{S}$ & $\mathrm{S}$ & $\mathrm{S}$ & & $\mathrm{S}$ & $\mathrm{S}$ & & $\mathrm{S}$ & $\mathrm{S}$ & & - \\
\hline Nitrate reduction & + & & - & - & + & & - & - & & - & - & & - \\
\hline ONPG & - & & - & - & - & & - & - & & - & - & & - \\
\hline Urease & - & & - & - & - & & - & $\mathrm{W}+$ & & $\mathrm{W}+$ & - & & + \\
\hline MR & + & & + & + & + & & + & + & & + & + & & + \\
\hline VP & - & & - & - & - & & - & - & & - & - & & - \\
\hline Oxidase & + & & + & - & + & & - & - & & - & + & & + \\
\hline Catalase & + & & + & + & + & & + & + & & + & + & & + \\
\hline Glucose & + & & + & + & + & & + & + & & + & + & & + , Gas \\
\hline Glycerol & - & & - & - & - & & - & $\mathrm{W}+$ & & - & - & &,+ Gas \\
\hline Maltose & + & & + & + & + & & - & + & & + & + & &,+ Gas \\
\hline Lactose & - & & - & - & $\mathrm{W}_{-}$ & & - & - & & - & - & &,+ Gas \\
\hline Sucrose & + & & + & + & + & & - & + & & - & + & & + \\
\hline Characteristic & TN5 & 352 & $\mathrm{~S}$ & MM2 & MA1 & TAH & KL & D & F34 & Xenorha & is sp. & Phot & abdus sp. \\
\hline Shape & Rod & Rod & Rod & Rod & Rod & Rod & Rod & Rod & Rod & Rod & & Rod & \\
\hline Form & Circular & Irregular & r Irregular & Irregular & Irregular & Circular & circular & Irregular & Irregular & - Irregular & & Circl & \\
\hline Pigmentation & - & - & - & - & - & - & - & - & - & + & & + & \\
\hline Gram stain & + & + & - & - & - & + & - & - & - & - & & - & \\
\hline Bioluminescence & - & - & - & - & - & - & - & - & - & - & & + & \\
\hline Motility & + & + & + & + & + & + & + & + & + & + & & + & \\
\hline Spore formation & - & - & + & - & - & - & - & - & - & - & & - & \\
\hline Nitrate reduction & - & - & - & - & - & - & - & - & - & - & & - & \\
\hline ONPG & - & - & - & - & - & - & - & - & - & $\mathrm{d}$ & & - & \\
\hline Urease & + & $\mathrm{W}+$ & $\mathrm{W}+$ & - & + & - & + & + & - & - & & d & \\
\hline MR & - & + & + & + & + & + & + & + & + & - & & - & \\
\hline VP & - & - & - & - & - & - & - & - & - & $\mathrm{d}$ & & - & \\
\hline Oxidase & + & - & - & + & + & + & + & - & - & - & & - & \\
\hline Catalase & + & + & + & + & + & + & + & + & + & - & & + & \\
\hline Glucose & + & + & + & + & + , Gas & + , Gas &,+ Gas & + & + & + & & + & \\
\hline Glycerol & W+ & - & - & $\mathrm{W}+$ & W+ & $\mathrm{W}+$ & - & + & + &,+ Gas & & + & \\
\hline Maltose & W+ & + & + & + & + , Gas &,+ Gas &,+ Gas & + & + &,+ Gas & & + & \\
\hline Lactose & W+ & - & - & $\mathrm{W}+$ & + & - & $\mathrm{W}+$ & - & $\mathrm{W}+$ & - & & - & \\
\hline Sucrose & W+ & - & - & + & + , Gas &,+ Gas &,+ Gas & + & + & - & & - & \\
\hline
\end{tabular}

+ positive, - negative, $W+$ weakly positive, $S$ spore formation, $V P$ Voges-Proskauer, $M R$ methyl red, Gas gas production, $d$ vary depending on species

genera such as Provindencia (proteus) rettgeri (Jackson et al. 1995); Enterobacter gergoviae, Vibrio spp., Pseudomonas fluorescens type C, Serratia marcescens, Citrobacter freundii, and Serratia proteomaculans (Gouge and Snyder 2006) from EPN. Association of $\gamma$ - proteobacterium Moraxella osloensis (Moraxellaceae) with the nematode Phasmarhabditis hermaphrodita (Rhabditidae) was reported by Tan and Grewal (2001) but the bacterium was phylogenetically distinct from either Xenorhabdus or Photorhabdus (Enterobacteriaceae). 
Fig. 1 Phylogenetic tree inferred from $16 \mathrm{~S}$ rDNA sequences analysis showing the relationships of Rhabditis (Oscheius) spp. associated EPB isolates with several members of the Proteobacteria

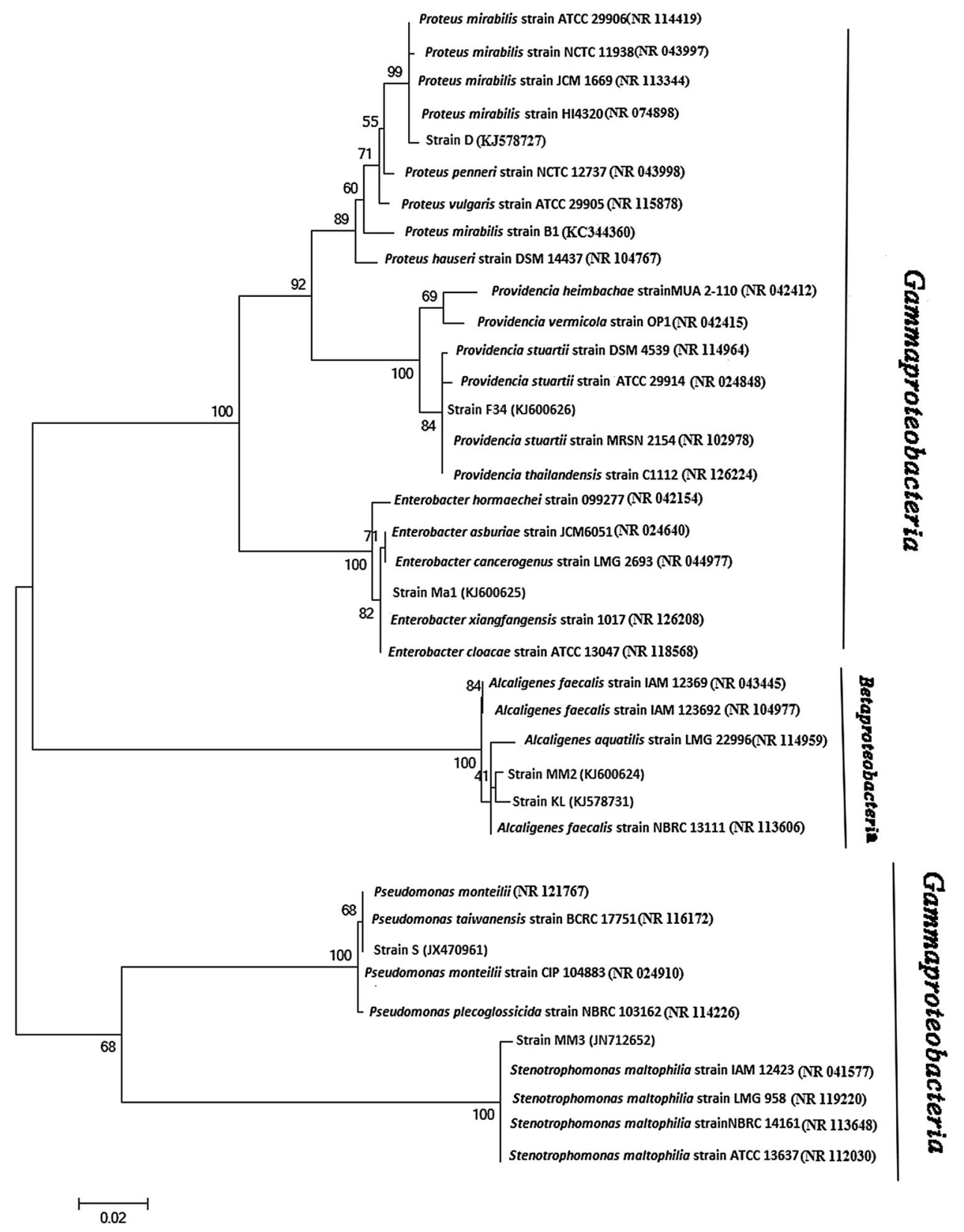

Symbiotic association of Serratia nematodiphila (Enterobacteriaceae) with a newly described EPN, Heterorhabditidoides chongmingensis which belongs to family Rhabditidae was reported by Zhang et al. (2009). All these studies revealed the association of $\gamma$-proteobacteria with EPNs.

Brunel et al. (1997) opined that restriction analysis of PCR-amplified 16S rDNA is a very effective technique for distinguishing between the bacterial symbionts of EPNs. Amplified Ribosomal DNA Restriction Analysis (ARDRA) of $16 \mathrm{~S}$ rDNA was used to distinguish the EPB strains associated with Rhabditis (Oscheius) sp. The isolates BR1, HY, KPG, KY1, KAL, KK2, SBI, and SCI were identified as $B$. cereus but six different restriction patterns were observed by this method. These results corroborate with the studies on Xenorhabdus and Photorhabdus conducted by Fischer-Le Saux et al. (1998). The isolates TN5 and TAH were identified as E. faecalis, but they also show variable restriction patterns. Detection of new genotypes and grouping of Xenorhabdus and Photorhabdus using PCRrestriction fragment length polymorphism (RFLP) and $16 \mathrm{~S}$ rDNA were reported by Akhurst (1996) and Brunel et al. (1997). All the bacterial isolates used in this study were also grouped into two heterogenous main clusters where group I comprises all the B. cereus, L. sphaericus, E. faecalis, P. mirabilis, Providencia sp. and Enterobacter sp. 
Fig. 2 Phylogenetic tree inferred from $16 \mathrm{~S}$ rDNA sequences analysis showing the relationships of Rhabditis (Oscheius) spp. associated EPB isolates with several members of the class Bacilli

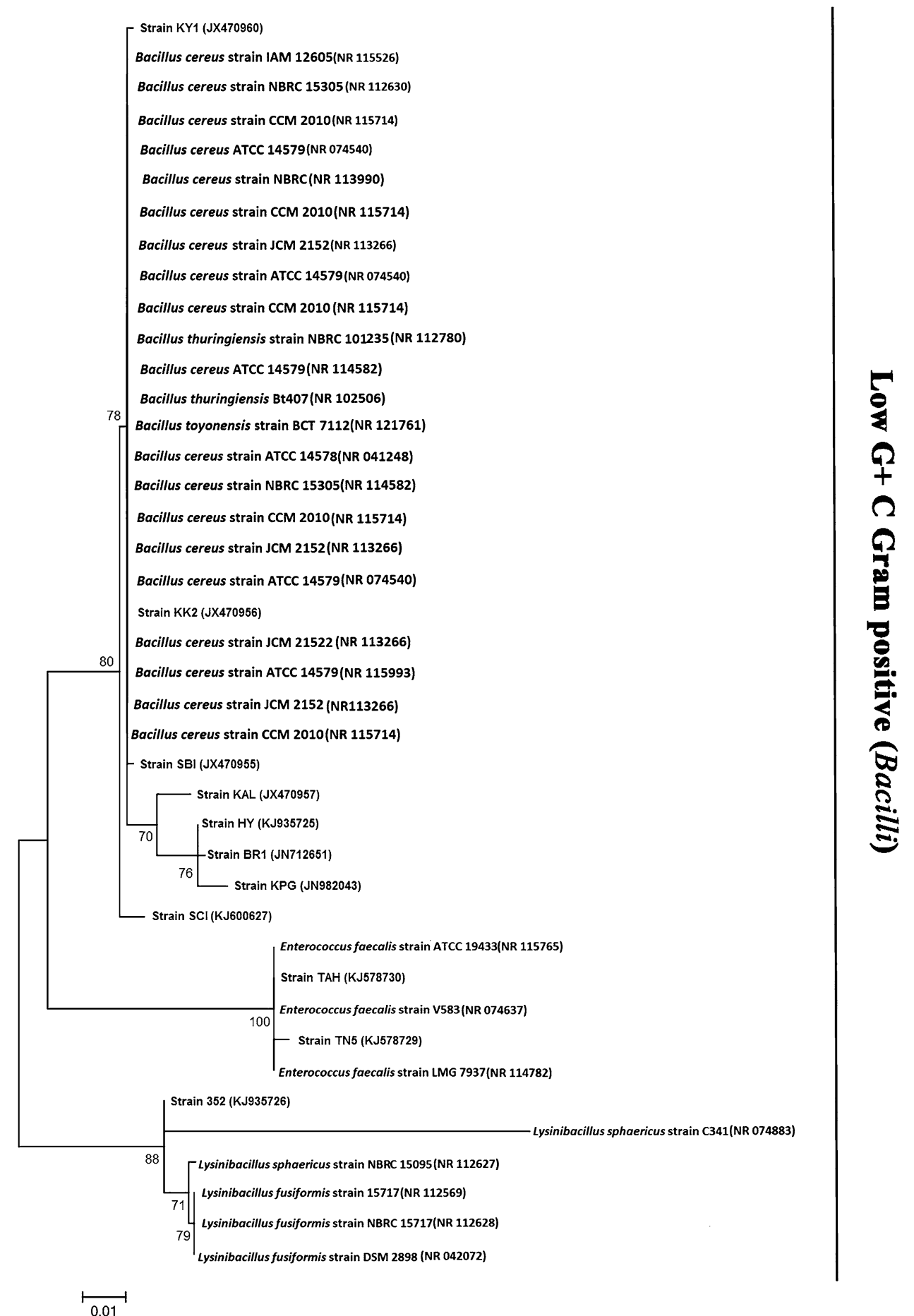

strains, whereas group II comprises Pseudomonas sp., S. maltophilia and A. faecalis. The clustering of the isolates may be due to the absence of variation in 16S rRNA genes among different bacterial species (Fox et al. 1992). It can also be explained by their shared environment, including a common host, which promoted the exchange of genetic material between the bacterial isolates. Entomopathogens in general have a history of horizontal gene transfer events, shuffling toxin containing plasmids and pathogenicity islands between each other (Castagnola and Stock 2014). The present study also reveals a group of novel EPB which will be useful for production of bioactive metabolites effective against bacterial and fungal diseases of plants and animals. 
Fig. 3 Restriction patterns of PCR-amplified 16S rRNA genes from bacterial strains digested with restriction endonuclease AluI
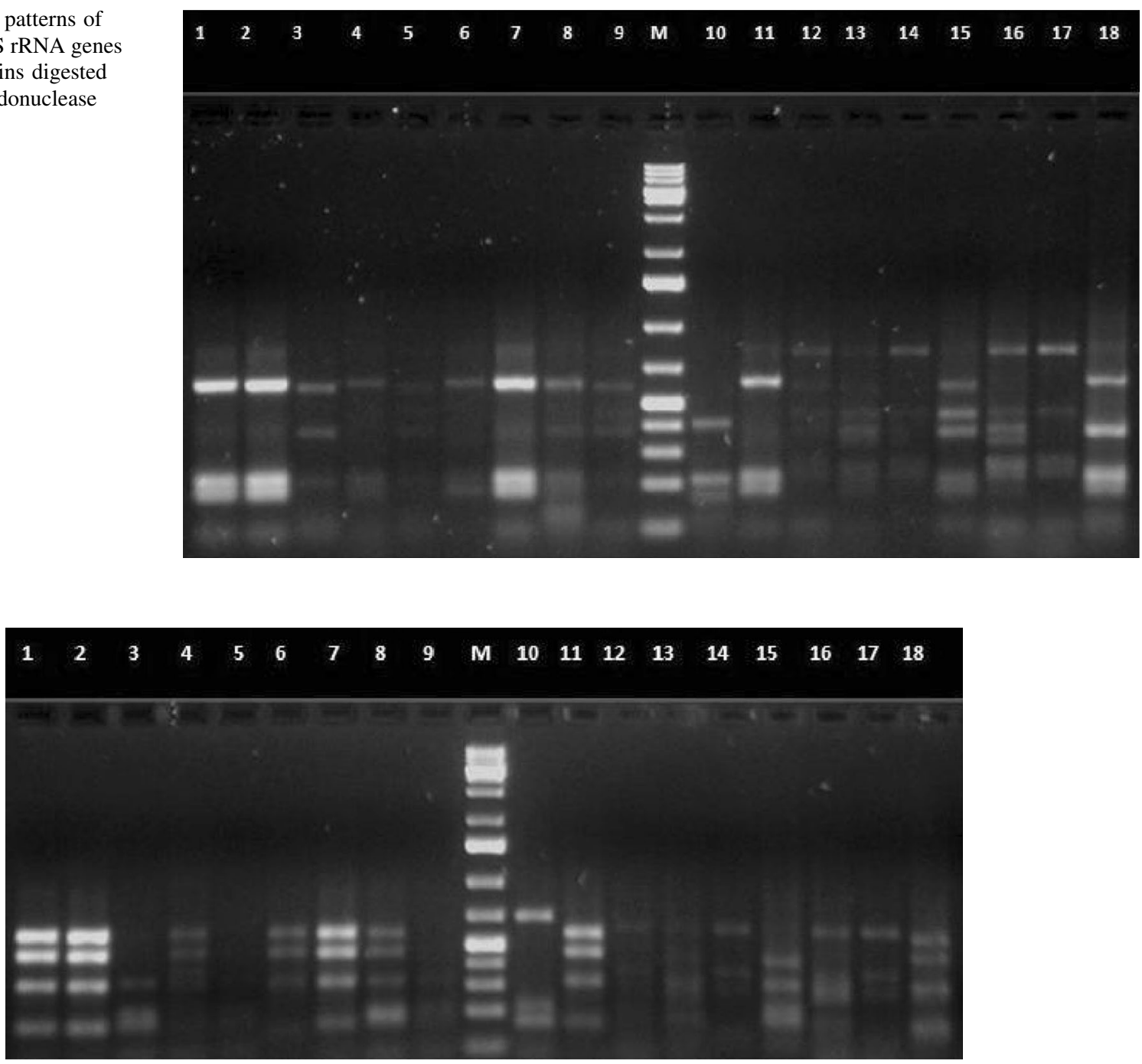

Fig. 4 Restriction patterns of PCR-amplified 16S rRNA genes from bacterial strains digested with restriction endonuclease HaeIII. Lane 1-8 Bacillus cereus KPG, BR1, KY1, SBI, KAL, SCI, KK2, HY, 9-Enterococcus faecalis TN5, M-1kbp plus ladder (Bangalore GeNei,
India), 10-Lysinibacillus sphaericus 352, 11-Pseudomonas sp. S, 12-Alcaligenes faecalis MM2, 13-Enterobacter sp.MA1, 14-Enterococcus faecalis TAH, 15-A. faecalis KL, 16-Proteus mirabilis D, 17-Providencia sp. F34, 18-Stenotrophomonas sp.MM3
Fig. 5 Dendrogram based on UPGMA cluster analysis obtained for the combined ARDRA restriction profiles

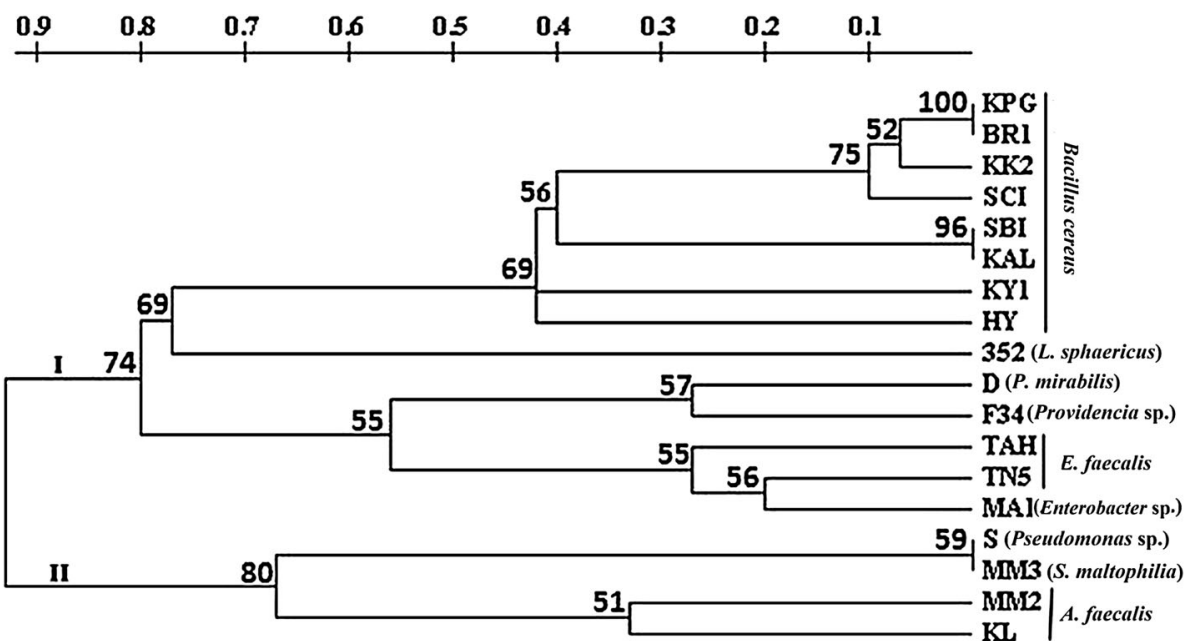

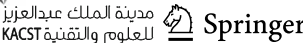




\section{Conclusion}

The detailed study on the metabolites produced by the novel bacteria associated with the EPN brings up a promising biocontrol agent which can manage pests and diseases in an ecofriendly manner.

Acknowledgments The first author is grateful to Council of Scientific and Industrial Research, Government of India for funding. We thank the Director, CTCRI, for providing facilities for the work.

\section{Compliance with ethical standards}

Conflict of interest The authors declare that they have no conflict of interest in the publication.

Open Access This article is distributed under the terms of the Creative Commons Attribution 4.0 International License (http:// creativecommons.org/licenses/by/4.0/), which permits unrestricted use, distribution, and reproduction in any medium, provided you give appropriate credit to the original author(s) and the source, provide a link to the Creative Commons license, and indicate if changes were made.

\section{References}

Akhurst RJ (1996) From then to now-a brief review of entomopathogenic nematodes and their symbiotic bacteria. In: Second international symposium on entomopathogenic nematodes and their symbiotic bacteria, pp 3-8

Akhurst RJ, Boemare NE (1990) Biology and taxonomy of Xenorhabdus. In: Gaugler R, Kaya H (eds) Entomopathogenic nematodes in biological control. CRC Press Inc, Boca Raton, pp 75-90

Bode HB (2009) Entomopathogenic bacteria as a source of secondary metabolites. Curr Opin Chem Biol 13:224-230

Boemare NE, Akhurst RJ (1988) Biochemical and physiological characterization of colony form variants in Xenorhabdus spp. (Enterobacteriaceae). J Gen Microbiol 134:751-761

Boemare NE, Akhurst RJ, Mourant RG (1993) DNA relatedness between Xenorhabdus spp. (Enterobacteriaceae), symbiotic bacteria of entomopathogenic nematodes, and a proposal to transfer Xenorhabdus luminescens to a new genus, Photorhabdus gen. nov. Int J Syst Evol Microbiol 43:249-255

Brunel B, Givaudan A, Lanois A, Akhrust RJ, Boemare N (1997) Fast and accurate identification of Xenorhabdus and Photorhabdus species by restriction analysis of PCR-amplified 16S rRNA genes. Appl Environ Microbiol 63:574-580

Cappuccino JG, Sherman N (1996) Microbiology—a laboratory manual. The Benjamin Publishing Company, New York

Castagnola A, Stock PS (2014) Common virulence factors and tissue targets of entomopathogenic bacteria for biological control of lepidopteran pests insects 5:139-166

Chaston JM, Suen G, Tucker SL, Andersen AW, Bhasin A et al (2011) The entomopathogenic bacterial endosymbionts Xenorhabdus and Photorhabdus: convergent lifestyles from divergent genomes. PLoS One 6(11):e27909

Christen JM, Campbell JF, Zurek L, Shapiro Ilan DI, Lewis EE, Ramaswamy SB (2008) Role of symbiotic and non-symbiotic bacteria in carbon dioxide production from hosts infected with Steinernema riobrave. J Invertebr Pathol 99:35-42

Clarridge JE (2004) Impact of 16S rRNA gene sequence analysis for identification of bacteria on clinical microbiology and infectious diseases. Clin Microbiol Rev 17:840-862
Deepa I, Mohandas C, Makesh KT, Siji JV, Prakash K (2010) Identification of new entomopathogenic nematodes (EPNs) based on sequences of D2-D3 expansion fragments of the 28 SrRNA. J Root Crops 36(2):227-232

Deepa I, Mohandas C, Siji JV (2011) Molecular characterization of novel symbiotic bacteria from entomopathogenic nematodes. In: National seminar on climate change and food security Jan 20-22, pp 399-404

Ehlers RU (2001) Mass production of entomopathogenic nematodes for plant protection. Appl Microbiol Biot 56:523-633

Enright MR, McInerney JO, Griffin CT (2003) Characterisation of endospore forming bacteria associated with entomopathogenic nematodes, Heterorhabditis spp. and description of Paenibacillus nematophilus sp. nov. Int J Syst Evol Microbiol 53:435-441

Fischer-Le Saux M, Mauleon H, Constant P, Brunel B, Boemare N (1998) PCR-ribotyping of Xenorhabdus and Photorhabdus isolates from the caribbean region in relation to the taxonomy and geographic distribution of their nematode hosts. Appl Environ Microbiol 64:4246-4254

Flanders KL, Miller JM, Shields EJ (1996) In vivo production of Heterorhabditis bacteriophora Oswego (Rhabditida: Heterorhabditidae), a potential biological control agent for soil-inhabiting insects in temperate regions. J Econ Entomol 89:373-380

Forst S, Clarke D (2002) Bacteria-nematodes symbiosis. In: Gaugler $\mathrm{R}$ (ed) Entomopathogenic nematology. CABI Publishing, London, pp 57-77

Fox GE, Wisotzkey JD, Jurtshuk JRP (1992) How close is close: 16S rRNA sequence identity may not be sufficient to guarantee species identity. Int J Syst Bacteriol 42:166-170

Forst S, Dowds B, Boemare N, Stackebrandt E (1997) Xenorhabdus and Photorhabdus spp.: bugs that kill bugs. Annu Rev Microbiol 51:47-72

Garrity GM, Brenner DJ, Krieg NR, Staley JR (eds) (2005) Bergey's Manual of Systematic Bacteriology: The gammaproteobacteria, 2nd edn, vol 2, Part B. Williams and Wilkins, New York, pp 1108

Goodrich-Blair H, Clarke DJ (2007) Mutualism and pathogenesis in Xenorhabdus and Photorhabdus: two roads to the same destination. Mol Microbiol 64:260-268

Gouge DH, Snyder JL (2006) Temporal association of entomopathogenic nematodes (Rhabditida: Steinernematidae and Heterorhabditidae) and bacteria. J Invertebr Pathol 91:147-157

Jackson T, Wang H, Nugent M, Griffin C, Burnell A, Dowds B (1995) Isolation of insect pathogenic bacteria, Providencia rettgeri, from Heterorhabditis spp. J Appl Bacteriol 78:237-244

Kaaya GP, Darji N (1989) Mortality in adult tsetse, Glossina morsitans morsitans, caused by entomopathogenic bacteria. J Invertebr Pathol 54:32-38

Kumar SN, Mohandas C, Siji JV, Rajasekharan KN, Nambisan B (2012a) Identification of antimicrobial compound, diketopiperazines, from a Bacillus sp. $\mathrm{N}$ strain associated with a rhabditid entomopathogenic nematode against major plant pathogenic fungi. J Appl Microbiol 113(4):914-924

Kumar SN, Siji JV, Rajasekharan KN, Nambisan B, Mohandas C (2012b) Bioactive stilbenes from a Bacillus sp. N strain associated with a novel rhabditid entomopathogenic nematode. Lett Appl Microbiol 54:410-417

Kumar SN, Mohandas C, Nambisan B (2014a) Purification, structural elucidation and bioactivity of tryptophan containing diketopiperazines, from Comamonas testosteroni associated with a rhabditid entomopathogenic nematode against major human-pathogenic bacteria. Peptides 53:48-58

Kumar SN, Mohandas C, Nambisan B, Sreerag RS, Jayaprakas CA (2014b) Cyclo(L-Pro-D-Arg): a new antibacterial and antitumour diketopiperazine from Bacillus cereus associated with a rhabditid entomopathogenic. Folia Microbiol 59:197-202 
Marti OG, Timper P (1999) Phoretic relationship between a Bacillus sp. and the entomopathogenic nematode, Heterorhabditis sp. J Nematol 31:553 (Abstr)

Mohandas C, Sheela MS, Sheeba M, Naveen Raj DS (2004) Rhabditis (Oscheius) spp. (Nematoda: Rhabditidae) a new pathogenic nematode of crop pests. In: National symposium on green pesticides for insect pest management. Feb 5-6, 2004, Abstr. pp 51-52

Mohandas C, Sheeba M, Firoza AJ, Rajamma P (2007) Bacteria associated with Rhabditis (Oscheius) spp. (Rhabditidae: Nematoda) for the biocontrol of insect pests. In: Proceedings of national seminar on achievements and opportunities in post harvest management and value addition in root and tuber crops (NSRTC-2), pp 195-198

Padmakumari AP, Prasad JS, Gururaj K, Sankar M (2007) Rhabditis sp. (Oscheius sp.), a biocontrol agent against rice yellow stem borer, Scirpophaga incertulas. Indian J Plant Prot 35:255-258

Park HW, Kim OY, Ha JS, Youn HS, Kim HH, Bilgrami AL, Shin CS (2011) Effects of associated bacteria on the pathogenicity and reproduction of the insect-parasitic nematode Rhabditis blumi (Nematoda: Rhabditida). Can J Microbiol 57:750-758

Park HW, Kim HH, Youn SH, Shin TS, Bilgrami AL, Cho MR, Shin CS (2012) Biological control potentials of insect-parasitic nematode Rhabditis blumi (Nematoda: Rhabditida) for major cruciferous vegetable insect pests. Appl Entomol Zool 47:389-397

Paul VJ, Frautschy S, Fenical W, Nealson KH (1981) Antibiotics in microbial ecology, isolation and structure assignment of several new antibacterial compounds from the insect symbiotic bacteria Xenorhabdus spp. J Chem Ecol 7:589-597

Poinar G (1990) Biology and taxonomy of Steinermatidae and Heterorhabditidae. In: Gaugler R, Kaya HK (eds) Entomopathogenic nematodes in biological control. CRC Press, Inc., Boca Raton, pp 23-62

Rainey FA, Ehlers RU, Stackebrandt E (1995) Inability of the polyphasic approach to systematics to determine the relatedness of the genera Xenorhabdus and Photorhabdus. Int J Syst Bacteriol 45:379-381

Reinhardt EL, Ramos PL, Gilson P, Manfio GP, Barbosa HR, Pavan C, Moreira-filho CA (2008) Molecular characterization of nitrogen-fixing bacteria isolated from Brazilian agricultural plants at São Paulo state. Braz J Microbiol 39:414-422

Snyder H, Stock SP, Kim SK, Flores-Lara Y, Forst S (2007) New insights into the colonization and release processes of Xenorhabdus nematophila and the morphology and ultrastructure of the bacterial receptacle of its nematode host, Steinernema carpocapsae. Appl Environ Microbiol 73:5338-5346 (20)

Swings J (1996) Exploration of prokaryotic diversity employing taxonomy. In: Allsopp D, Colwell RR, Hawksworth DL (eds)
Microbial diversity and ecosystem function. CAB International, Egham, p 482

Tamura K, Stecher G, Peterson D, Filipski A, Kumar S (2013) MEGA6: molecular evolutionary genetics analysis version 6.0. Mol Biol Evol 30:2725-2729

Tan L, Grewal SP (2001) Pathogenicity of Moraxella osloensis, a bacterium associated with the nematode Phasmarhabditis hermaphrodita, to the slug Deroceras reticulatum. Appl Environ Microbiol 67:5010-5016

Tiedje JM (1996) Approaches to the comprehensive evaluation of prokaryote diversity of a habitat. In: Allsopp D, Colwell RR, Hawksworth DL (eds) Microbial diversity and ecosystem function. CAB International, Egham, p 482

To WN, Gudauskas RT, Harper JD (1975) Pathogenicity of Bacillus cereus isolated from Trichoplusia ni larvae. J Invertebr Pathol 26:135-136

Walsh KT, Webster JM (2003) Interaction of microbial populations in Steinernema (Steinernematidae, Nematoda) infected Galleria mellonella larvae. J Invertebr Pathol 83:118-126

Warren GW, Koziel MG, Mullins MA, Nye GJ, Carr B, Desai NM, Kostichka K, Duck NB, Estruch JJ (1996) Novel pesticidal proteins and strains. USA Patent No. WO96/10083

Webster JM, Chen G, Hu K, Li J (2002) Bacterial metabolites. In: Gaugler R (ed) Entomopathogenic nematology. CABI Publishing, Willingford, p 388

Weisburg WG, Barns SM, Pelletier DA, Lane DJ (1991) 16S ribosomal DNA amplification for phylogenetic study. J Bacteriol 173:697-703

Woodring JI, Kaya HK (1988) Steinernematid and Heterorhabditid nematodes: a hand book of biology and techniques. Southern Cooperative Series Bulletin 331. Arkansas Agricultural Experimental Station, Fayetteville, USA

Zhang C, Liu J, Xu M, Sun J, Yang S, An X, Gao G, Lin M, Lai R, He Z, Wu Y, Zhang K (2008) Heterorhabditidoides chongmingensis gen. nov., sp. nov. (Rhabditida: Rhabditidae), a novel member of the entomopathogenic nematodes. J Invertebr Pathol 98:153-168

Zhang CX, Yang SY, Xu MX, Sun J, Liu H, Liu JR, Liu H, Kan F, Sun J, Lai R, Zhang KY (2009) A novel species of Serratia, family Enterobacteriaceae: Serratia nematodiphila sp.nov., symbiotically associated with entomopathogenic nematode Heterorhabditidoides chongmingensis (Rhabditida: Rhabditidae). Int J Syst Evol Microbiol 59:1603-1608

Zhang KY, Liu XH, Tan J, Wang Y, Qiao L, Yedid G, Dai CS, Qiu RL, Yan XW, Tan HW, U ZY, Lai R, Gao GF (2012) Heterorhabditidoides rugaoensis $\mathrm{n}$. sp. (Rhabditida: Rhabditidae), a novel highly pathogenic entomopathogenic nematode member of Rhabditidae. J Nematol 44:348-360 